anderen Mastgruppe war (ein Drittel der Paare war uniform, $2 / 3$ geteilt) bzw. aus der Höhe der genetischen Korrelation zwischen denselben Merkmalen bei verschiedenen Mastmethoden.

Während Milchmastkälher hohe Gaben Vollmilchaustauscher bis zur Schlaschtung im Alter von 14 Wochen erhielten, wurden die anderen beiden Gruppen (Jungstiere, zukünft. Ochsen) nach milcharmer Aufzucht mit 6 Wochen abgesetzt und mit Heu und Kraftfutter (bis zu $2 \mathrm{~kg}$ tägl.) gefüttert. Bei 3 Monate Alter waren die genetischen Korrelationen für Körpergewitch, Gewicht/Alter, Widerristhöhe (WH), Körperlänge, Brustumfang (BU), Spiralmass (SPM), BU/WH und SPM/WH, in derselben Reihenfolge $0.59,0.73,1,1,0.66,1,1$ und 1 (die Werte sind für verschiedene Skalen korrigiert).

\title{
INVESTIGATIONS ON CORRELATIONS BETWEEN MILK PRODUCTION AND BODY WEIGHT OF THE COW IN THE HUNGARIAN RED PIED, RI) $M$ AND FINNISH AYRSHIRE BREEDS
}

\author{
J. DoHy. - Institute for Animal, Breeding University of Veterinary Sciences, \\ Budapest, Rottenbiller U. 23-25, Hungary.
}

It has heen found a loose but significant correlation between body weight and milk yield of the cow, or -- if adult cows were investigated _ no correlation could have been disclosed. Between body weight (mass) and relative milk production has been found a significant negative correlation. The relative milk production (FCM : $100 \mathrm{~kg}$ hody weight) indicates a strong positive correlation with the absolute milk production and with the efficiency of fodder conversion. The heritability of the relative milk production has been established $h^{2}=0.56$ on the basis of the data of the danish progeny-testing stations. On account of importance of the relative milk production and of the early sexual maturity the author proposes to take the index of relative milk production per day of life into consideration regarding the ranking of progeny tested bulls :

$$
\frac{\text { FCM } 100}{(\text { chest girth, dm })^{2} / \text { number of days of life }} \cdot 100
$$

The values of this index mean : over 145 points record, between 120 and 145 points excellent, between 88 and 119 points good, between 66 and 87 points average, between 48 and 65 points poor, under 48 points very poor results, concerning cows having one lactation of 300 days.

\section{Divers}

\section{PREMIERS RÉSULTATS D'UNE EXPÉRIENCE DE SÉLECTION RÉALISÉE DANS UN CENTRE D'INSÉMINATION ARTIFICIEILIE PORCINE.}

\author{
L. OLIIVIER. - Station de Génétique quantitative et appliquée, I.N.R.A. \\ 78-Jouy-en-Josas, France.
}

Une expérience a été entreprise en 1966 au Centre expérimental d'Insémination artificielle de Rouillé (Vienne), dans le but d'évaluer l'efficacité d'une sélection individuelle sur indice chez le porc. Chacque année 50 jeunes mâles, répartis en dix familles de 5 demi-frères chacune, étaient soumis individuellement à des contrôles de croissance et dalimentation entre 30 et 80 kilogrammes de poids vif. Dans chaque famille, le meilleur verrat était retenu, en fonction 